\title{
Cloning of the Gene Cluster Responsible for the Biosynthesis of Brasilicardin A, a Unique Diterpenoid
}

\author{
Yutaka Hayashi, Nobuyasu Matsuura, Hiroaki Toshima, Nobuya Itoh, Jun Ishikawa, \\ Yuzuru Mikami, Tohru Dairi
}

Received: December 27, 2007/Accepted: March 11, 2008

(C) Japan Antibiotics Research Association

\begin{abstract}
Brasilicardin A (BCA), produced by Nocardia brasiliensis IFM 0406 (currently referred to as $N$. terpenica), has a unique structure consisting of a diterpene skeleton with L-rhamnose, $\mathrm{N}$-acetylglucosamine, amino acid, and 3-hydroxybenzoate moieties, and exhibits potent biological activities. To understand the biosynthetic machinery of this unique compound, we have cloned the corresponding gene cluster. Firstly, we cloned a gene by PCR that encodes geranylgeranyl diphosphate synthase (GGPPS), which produces a direct precursor of diterpene compounds. We obtained four candidate genes and one of the genes was confirmed to encode a GGPPS. By sequence analysis of regions flanking the GGPPS gene, we identified eleven genes (bral-11), all oriented in the same direction. We did not, however, detect any genes related to Lrhamnose and $N$-acetylglucosamine biosyntheses in the flanking regions. A gene disruption experiment did indeed show that this gene cluster was responsible for $\mathrm{BCA}$ biosynthesis.
\end{abstract}

Keywords Nocardia brasiliensis, brasilicardin A, diterpene, cloning, biosynthetic genes.

T. Dairi (Corresponding author), Y. Hayashi, N. Itoh: Biotechnology Research Center, Toyama Prefectural University, Toyama 939-0398, Japan, E-mail: dairi@pu-toyama.ac.jp

N. Matsuura: Department of Life Science, Okayama University of Science 700-0005, Japan

H. Toshima: Department of Bioresource Science, College of Agriculture, Ibaraki University, Ibaraki 300-0393, Japan

J. Ishikawa: Department of Bioactive Molecules, National Institute of Infectious Diseases, Shinjuku-ku 162-8640, Japan

Y. Mikami: Medical Mycology Research Center, Chiba University, Chiba 260-8673, Japan

\section{Introduction}

Isoprenoids are the largest single family of compounds found in nature, with over 24,000 known examples, and contain industrially useful compounds, such as flavors, antibiotics, and plant hormones [1]. All isoprenoid compounds are biosynthesized from the corresponding polyprenyl diphosphate [2]. Geranyl diphosphate gives rise to monoterpenes [3], farnesyl diphosphate to sesquiterpenes [4], and geranylgeranyl diphosphate to diterpenes [5]. In eukaryotes, such as plants and fungi, which produce the vast majority of isoprenoids, the polyprenyl diphosphate is usually cyclized by an organism specific isoprenoid cyclase to make a basic skeleton, followed by successive reactions such as hydroxylation, methylation, and glycosylation, etc, to give many thousands of compounds [3 8].

In contrast to eukaryotes, prokaryotes are known to produce a limited number of isoprenoids. Among prokaryotes, actinomycete strains have been found to produce several isoprenoid compounds. To date, sesquiterpene cyclases, such as pentalenene synthase [9], (+)-epi-isozizaene synthases [10], and geosmin synthase [11], have been identified and characterized. We have also cloned several diterpene cyclase genes from actinomycetes [12 16]. All these isoprenoid cyclases were known to accept substrates that are biosynthesized from isopentenyl diphosphate, such as farnesyl diphosphate (FPP) and geranylgeranyl diphosphate (GGPP), in a similar manner to eukaryotic enzymes. On the other hand, it was recently revealed that the structures of many isoprenoids produced by actinomycetes have mixed biosynthetic origin [16]. In many cases, isoprenoid moieties of compounds are attached to other moieties, such as a polyketide, an aromatic ring, an 


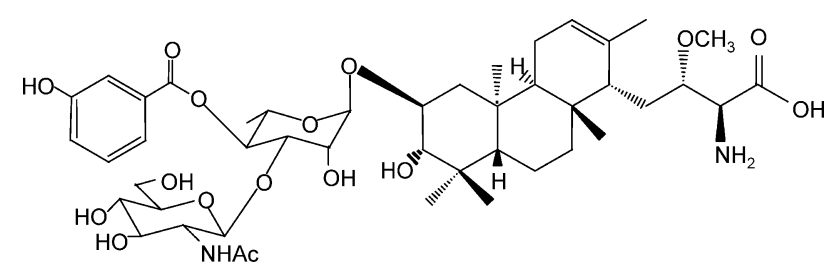

Fig. 1 Structure of brasilicardin A.

amino acid, etc, that have been synthesized via pathways that are independent of isoprenoid synthesis, to give socalled "isoprenoid-hybrid compounds" [16]. Brasilicardin A (BCA), produced by Nocardia brasiliensis IFM 0406, is a representative of this type of compound, which consists of a basic diterpene skeleton with L-rhamnose, $\mathrm{N}$ acetylglucosamine, amino acid, and hydroxybenzoate moieties (Fig. 1) [17]. BCA was demonstrated to possess potent anti-tumor [18] and immunosuppressive activity [19]. Derivatives of BCA have been chemically synthesized to search for novel compounds with high immunosuppressive activity and to examine the relationship between BCA-structures and immunosuppressive activities [20].

In this study, we cloned the BCA biosynthetic gene cluster, as a first step to understanding the biosynthetic machinery of this unique and pharmaceutically important compound. A gene disruption experiment was also performed to examine whether the gene cluster identified in this study is indeed responsible for BCA biosynthesis.

\section{Experimental}

\section{Chemicals}

$\left[\alpha^{-32} \mathrm{P}\right] \mathrm{dCTP}$ was obtained from GE Healthcare UK Ltd. (Little Chalfont, England). Isopentenyl diphosphate (IPP), dimethylallyl diphosphate (DMAPP), FPP, and GGPP were purchased from Sigma-Aldrich (St. Louis, MO). All other chemicals were analytical grade. Authentic BCA was kindly provided by Kikkoman Co., Ltd. (Chiba, Japan).

\section{Bacterial Strains}

Nocardia brasiliensis IFM 0406 was used in the cloning experiment. Media and growth conditions for IFM 0406 were as described by Komaki et al. [17]. Escherichia coli JM110 and plasmids, pUC118 and pUC119, were used for sequence analysis. When necessary, ampicillin was added to the medium to a final concentration of $100 \mu \mathrm{g} / \mathrm{ml}$.

\section{DNA Isolation and Manipulation}

Plasmids from E. coli were prepared using a Qiagen plasmid kit (Hilden, Germany). All restriction enzymes, T4 ligase, and calf intestinal alkaline phosphatase were obtained from Toyobo and used according to the manufacturer's protocols. Transformation of $E$. coli with plasmid DNA by electroporation was performed under standard conditions using a BTX ECM 600 electroporation system (Biotechnologies and Experimental Research, San Diego, CA). Other general procedures were performed as described by Maniatis et al. [21].

\section{Cloning of Polyprenyl Diphosphate Synthase Genes by PCR}

Three sets of primers were designed, based on the conserved amino acid sequences of polyprenyl diphosphate synthase genes, which had been cloned from terpentecin [22], furaquinocin $\mathrm{A}[14,15]$, and $\mathrm{BE}-40644$ [23] producers: PDS-1-5; 5'-(C/G/T)T(C/G)CACGACGAC$(\mathrm{C} / \mathrm{G} / \mathrm{T}) \mathrm{T}(\mathrm{C} / \mathrm{G}) \mathrm{AT}(\mathrm{C} / \mathrm{G}) \mathrm{GAC}(\mathrm{A} / \mathrm{C} / \mathrm{G})(\mathrm{A} / \mathrm{G})(\mathrm{C} / \mathrm{G})-3^{\prime}$, PDS$1-3 ; 5^{\prime}-(\mathrm{C} / \mathrm{G}) \mathrm{A}(\mathrm{C} / \mathrm{G}) \mathrm{GTCGTC}(\mathrm{C} / \mathrm{G})(\mathrm{A} / \mathrm{C})(\mathrm{C} / \mathrm{G})(\mathrm{C} / \mathrm{G})-$ $(\mathrm{A} / \mathrm{G})(\mathrm{A} / \mathrm{G}) \mathrm{CTGGAA}(\mathrm{C} / \mathrm{G}) \mathrm{GC}-3^{\prime}$, PDS-2-5; 5'-(C/T)T$(\mathrm{C} / \mathrm{G})(\mathrm{C} / \mathrm{T}) \mathrm{T}(\mathrm{C} / \mathrm{G}) \mathrm{CACGACGACGT}(\mathrm{C} / \mathrm{G})(\mathrm{A} / \mathrm{G}) \mathrm{T}(\mathrm{C} / \mathrm{G}) \mathrm{G}$ $\operatorname{ACG}(\mathrm{A} / \mathrm{C})(\mathrm{C} / \mathrm{G})-3$ ', PDS-2-3; 5'-GTCGTC(C/G)A(C/T)(C/G)A(A/G/T)CTGGAA(C/G)GC(C/G)(A/G)T(C/G)CC3', PDS-3-5; 5'-GC(C/G)ATC(C/T)T(C/G)GC(C/G)GG$(\mathrm{C} / \mathrm{G}) \mathrm{GAC}(\mathrm{C} / \mathrm{G} / \mathrm{T}) \mathrm{T}(\mathrm{C} / \mathrm{G})(\mathrm{A} / \mathrm{T}) \mathrm{T}-3^{\prime}$, PDS-3-3; and 5' $(\mathrm{C} / \mathrm{G}) \mathrm{A}(\mathrm{C} / \mathrm{G}) \mathrm{GTCGTC}(\mathrm{C} / \mathrm{G})(\mathrm{A} / \mathrm{C})(\mathrm{C} / \mathrm{G})(\mathrm{C} / \mathrm{G})(\mathrm{A} / \mathrm{G})(\mathrm{A} / \mathrm{G})$ CTGGAA(C/G)GC-3'. These primers were used in PCR experiments to amplify polyprenyl diphosphate synthase (PDS) genes from genomic DNA of strain IFM 0406. The standard PCR amplification was performed with Takara LA PCR kit (Takara Bio Inc., Kyoto, Japan) under the following conditions: denaturation at $94^{\circ} \mathrm{C}$ for 1 minute, annealing at $50^{\circ} \mathrm{C}$ for 1 minute, elongation at $72^{\circ} \mathrm{C}$ for 1.5 minutes, 30 cycles. When necessary, annealing temperature was varied and other DNA polymerases, such as KOD- and Pfu-DNA polymerases (Toyobo), were used instead of Taqderived DNA polymerase. The amplified DNA fragments were inserted into pGEM-T easy vector (Promega, Madison, WI) and were then used for sequence analysis. A cosmid library of strain IFM 0406, which was constructed by the same method as described previously [24], was screened by colony hybridization, using ${ }^{32} \mathrm{P}$-labeled amplified fragments as probes. Positive cosmids were selected and DNA fragments that again hybridized to the probe by Southern blot analysis were subcloned into pUC119. After construction of a series of plasmids, sequencing was performed with an automatic DNA sequencer (Li-Cor, Model 4000L, Lincoln, NE).

\section{Overproduction of the GGPPS in $E$. coli}

The following primers were used to amplify the ggppl 
gene: 5'-CATGCATGCACCCGCTACGCCGTGCAGCCGCCGGG-3' (forward) and 5'-CACAAGCTTTCACCACGTGCGCCCGATCATGCTGT-3' (reverse). PCR was carried out under standard conditions. After sequence confirmation, a 0.9-kb SphI-HindIII fragment was inserted into the same sites of pQE30. A plasmid, pQE30-ggpps, in which a recombinant protein was expressed as an $\mathrm{N}$ terminal $6 \mathrm{x}$ His-tagged fusion protein, was selected.

E. coli M15 [pREP4] harboring pQE30-ggpps was grown at $37^{\circ} \mathrm{C}$ in Luria-Bertani broth medium with appropriate antibiotics. Expression of the recombinant protein was induced by adding $0.1 \mathrm{mM}$ of isopropyl- $\beta$-Dthiogalactoside when $\mathrm{OD}_{600}$ reached about 0.8 . Cultivation was continued for an additional 12 hours at $18^{\circ} \mathrm{C}$. Purification of His-tagged recombinant protein was performed according to the manufacturer's protocol (Qiagen). Purified proteins were analyzed by SDS-PAGE on $10 \%$ gels and used in an in vitro enzyme assay to determine the product chain length. Assay conditions and product analysis were performed as described previously [25].

\section{Disruption of the Cyclase Gene}

The bra 4 encoding a cyclase gene was disrupted by a double crossover event. A $3.0 \mathrm{~kb} H i n \mathrm{dIII} / B g l \mathrm{II}$ DNA fragment and a $2.5 \mathrm{~kb} \mathrm{BglII/HindIII} \mathrm{DNA} \mathrm{fragment,} \mathrm{which}$ carried the upstream region and the downstream region of the bra 4 gene, respectively, were amplified by PCR with the following two sets of primers: 5'-ACCAAGCTTGCGGAGGGTCCGGTGATGGTGAATTC-3' and 5'GAAGATCTGCCGACCTCACAGGGATATCGCCGAAT3'; 5'-GAAGATCTTGGAACCGACGCCGACGCCGTGGTGTG-3' and 5'-ACCAAGCTTCTACCACGTCACCGGAAGCCGACGAA-3'. After sequence confirmation, these two fragments and HindIII-digested pUC118 were ligated and introduced into E. coli. A plasmid carrying the appropriate DNA fragments was selected. A $0.8 \mathrm{~kb} \mathrm{BclI}$ fragment that carried a thiostrepton resistance gene was prepared from pIJ702 [26] and was then inserted into $B g l \mathrm{II}$ site of the plasmid, which existed between the PCRamplified fragments. This plasmid was then digested with HindIII and the resultant fragment was inserted into the same sites of pK18mob [27] to construct pCyc-DIS. The plasmid was used for disruption of the chromosomal bra 4 gene by double crossover recombination. Introduction of the plasmid from E. coli into the BCA producer was performed by transconjugation and thiostrepton resistant colonies were selected [28]. Genomic DNAs were prepared from the transconjugants and subjected to PCR analysis with the following primers: 5'-GTGAGCGCGCGCACCCGGCGGCACTGGTGGGCGCA-3' and 5'-AGCGT-
GGCCGCGACATCGAGGAGGCGATGTGCTGA-3', which corresponded to the $N$-terminal and $C$-terminal coding region of the bra 3 and bra5 genes. The productivity of BCA by the disruptant was examined as follows: The disruptants were cultivated by the methods described by Komaki et al. [17], except for the addition of thiostrepton $(50 \mu \mathrm{g} / \mathrm{ml})$ to the medium. After full growth cultivation, the culture broth was centrifuged, and compounds were extracted by ethyl acetate from the supernatant. Compounds were analyzed by HPLC: column, LiChroCART 125-4.0 Superspher 100 RP-18, Kanto Chemical, Tokyo, Japan; Mobile phase, $18 \% \mathrm{CH}_{3} \mathrm{CN}$ containing TFA $(0.15 \%)$ for 0 to 30 minutes, and $50 \%$ $\mathrm{CH}_{3} \mathrm{CN}$ containing TFA $(0.15 \%)$ for an additional 10 minutes; flow rate, $1.0 \mathrm{ml} /$ minute; detection $220 \mathrm{~nm}$.

\section{Nucleotide Sequence Accession Number}

The DNA sequences determined in this study are deposited in the DDBJ, EMBL, and GenBank databases under accession numbers AB264550 (BCA biosynthetic gene cluster) and AB268547 (a sugar biosynthetic gene cluster).

\section{Results}

\section{Cloning of a ggpps Gene by PCR}

We found recently that biosynthetic genes of terpentecin [12] and 3-hydroxypimeradiene (viguiepinol) [14, 15], both of which are diterpene compounds produced by actinomycetes, were located in flanking regions of the genes encoding geranylgeranyl diphosphate synthase (GGPPS), which supplies a direct precursor of diterpene compounds. Hence, we first tried to clone a GGPPS gene in order to use it as a probe to clone an entire BCA biosynthetic gene cluster. To date, many deduced amino acid sequences of PDS, including GGPPS, have been reported. For example, we could identify at least six PDS genes in both Streptomyces coelicolor A3(2) (SCO185, SCO565, SCO568, SCO4583, SCO5250, and SCO6763) and $S$. avermitilis (SAV1022, SAV1129, SAV1651, SAV2997, SAV3006, and SAV4864), the entire genome sequences of which have been determined [29, 30]. Furthermore, we have identified four PDS genes in $S$. argenteolus, a unique tetraterpene compound, KS-505a, producer [31]. These facts suggested that an actinomycete BCA producer has several PDS genes. Hence, we tried to clone multiple putative PDS genes by using multiple sets of primers, which were designed based on the conserved amino acid sequences of PDSs, and by varying the PCR conditions, such as annealing temperatures and $\mathrm{Mg}^{2+}$ concentration. 
We amplified and cloned four kinds of DNA fragments (ggpps1 ggpps4), all of which are thought to encode enzymes similar to PDSs. By sequence analysis, we did not find any genes related to isoprenoid biosynthesis in the flanking regions of ggpps 3 or ggpps 4 . The ggpps 2 locus suggested that it constituted an operon, with a gene that encodes an enzyme similar to squalene-hopene cyclase, in a manner similar to that observed in S. coelicolor A3(2) (SCO6763 and SCO6764), S. avermitilis MA-4680 (SAV1650 and SAV1651), and S. argenteolus (a putative cyclase and opds2 gene) [31]. In contrast, ggpps 1 constituted an operon together with a prenyl transferase

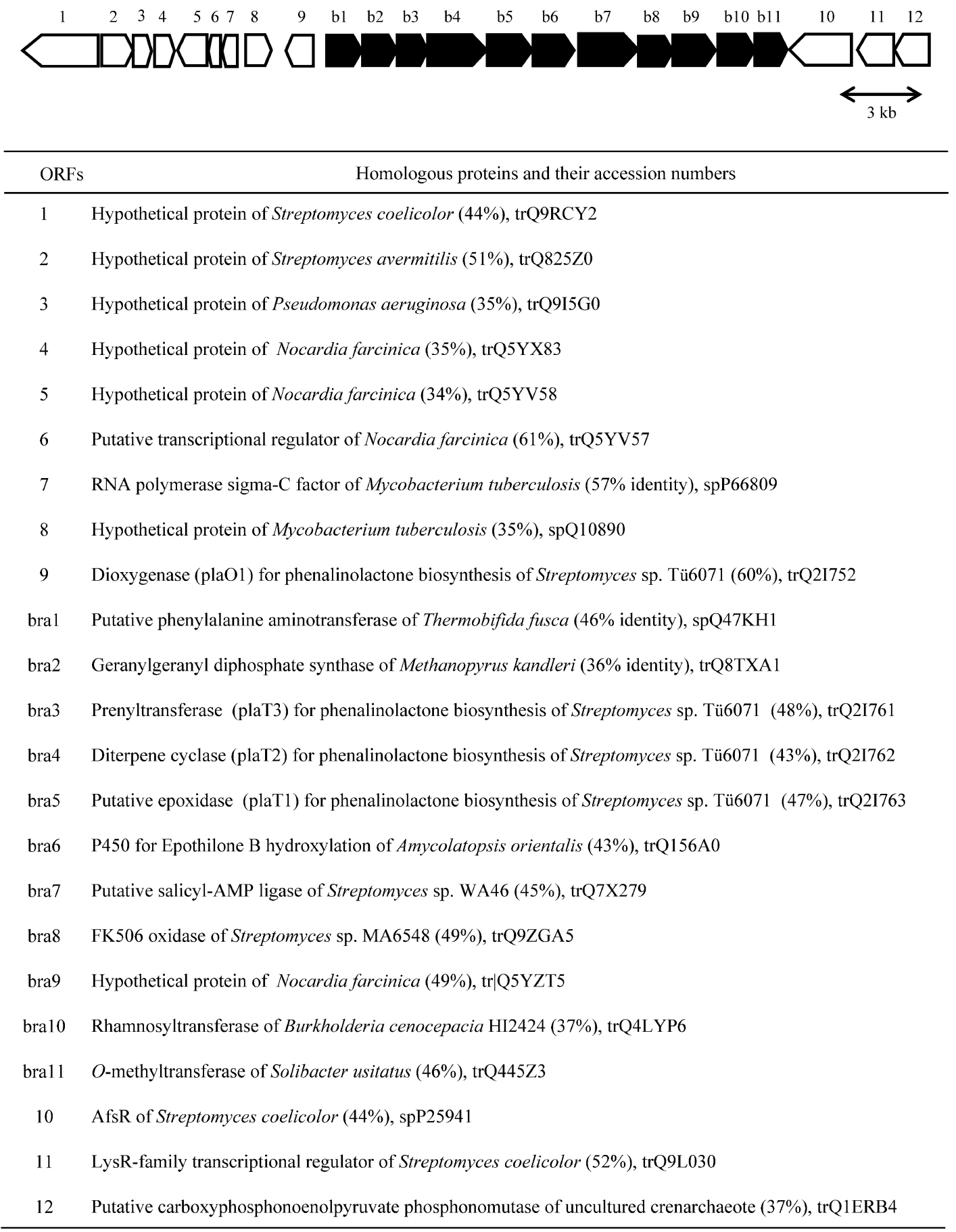

Fig. 2 Geranylgeranyl diphosphate synthase gene and its flanking regions in Nocardia brasiliensis.

ORFs deduced by sequence analysis are shown. Filled arrows and open arrows represent the putative BCA biosynthetic genes (bra genes) and the BCA-unrelated genes, respectively. sp, Swissplot; tr, UniProt (Universal Protein Resource). 
homologue (bra3) and a putative isoprenoid cyclase (bra4) (Fig. 2), both of which possibly participate in the biosynthesis of BCA. Hence, we first examined whether ggpps 1 encodes a GGPPS by producing a recombinant enzyme.

A recombinant ggpps 1 product was expressed in E. coli as an $N$-terminal His-tagged fusion protein, and an in vitro assay was performed. Soluble protein extracts from $E$. coli harboring pQE-GGPPS and pQE30 (no insert) were analyzed by SDS-PAGE. The His-tagged ggpps 1 product was expressed at a high level. The enzyme was then purified (Fig. 3) and used in the enzyme assay. When the assay was carried out using DMAPP and $\left[1-{ }^{14} \mathrm{C}\right]$ IPP as substrates, geranylgeraniol (C20) was clearly detected as a major product by TLC analysis (Fig. 3), suggesting that the ggpps 1 gene encodes a GGPPS, as expected.

\section{Cloning and Identification of the BCA Biosynthetic \\ Gene Cluster}

Considering that antibiotic biosynthesis genes cloned from actinomycetes are usually clustered in the genome, all genetic information for the biosynthesis of BCA was expected to reside in the flanking region of the ggpps 1
(A)

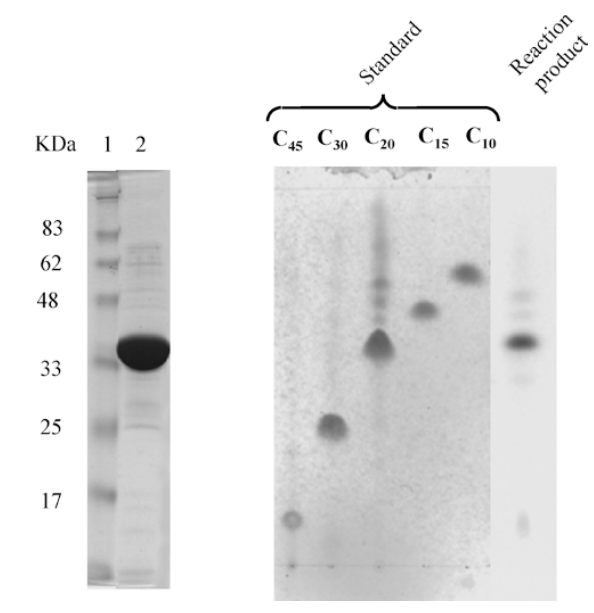

Fig. 3 Electrophoresis of the overproduced and purified bra2 product (A) and TLC autoradiography of the alcohols obtained by hydrolysis of the products (B).

A, Molecular mass marker (lane 1) and purified His-tagged bra2 product (lane 2) were analyzed on SDS-PAGE (12.5\%). Proteins were stained with Coomassie brilliant blue R-250. B, The sample obtained by incubation of $\left[1-{ }^{14} \mathrm{C}\right]$ IPP and DMAPP with the recombinant enzyme was analyzed by TLC. Spots of authentic standard alcohols $\left(\mathrm{C}_{10}\right.$ to $\left.\mathrm{C}_{45}\right)$ are also shown.

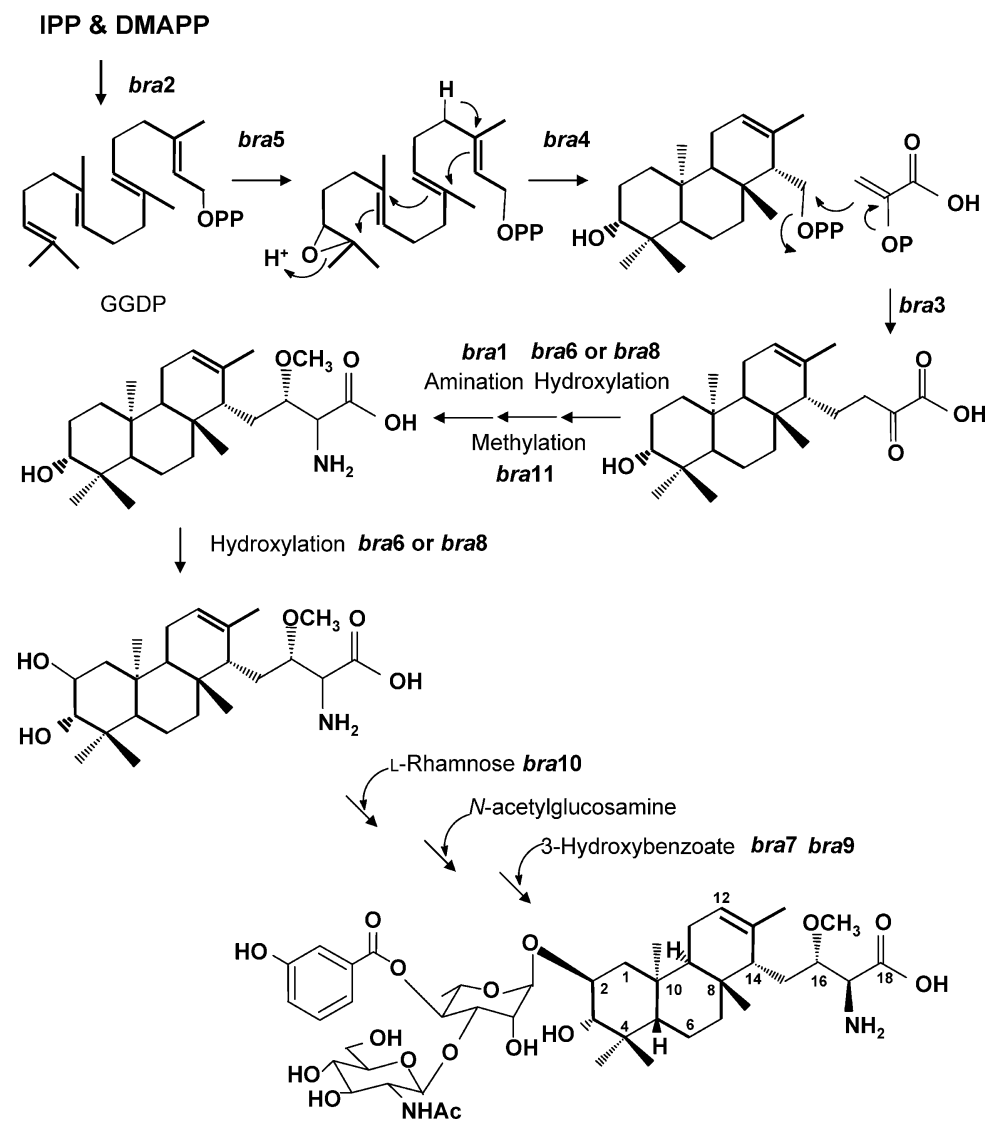

Fig. 4 Proposed biosynthetic pathway of BCA. 
gene. Hence, the nucleotide sequences of both the region upstream of ggpps 1 ( $b r a 2$ ) and of the region downstream of the putative isoprenoid cyclase genes (bra4) were determined. We identified 11 genes, all oriented in the same direction. To understand the functions of individual ORFs determined by DNA sequencing, we searched the public databases with FASTA and BLAST programs $[32,33]$. The results are summarized in Fig. 2. In brief, each of the gene products had a significant similarity to one of: NikT-like amino-transferase responsible for nikkomycin biosynthsis (bra1), GGPPS (bra2, ggpps1), prenyltransferase (bra3), isoprenoid cyclase (bra4), FAD-epoxidase (bra5), P450 (bra6), 2,3-dihydroxybenzoate-AMP ligase ( $b r a 7$ ), oxidase (bra8), hypothetical protein (bra9), dTDP-rhamnose transferase (bra10), methyl transferase (bra11). Among them, bra3, bra4, and bra 5 products had high amino acid identities to plaT3, plaT2, and plaT1 products, respectively, all of which were recently cloned from Streptomyces sp. Tü6071 and confirmed to participate in the early step of biosynthesis of phenalinolactone, a diterpene compound [34]. Since the early step of the proposed biosynthetic pathway of phenalinolactone was thought to be identical of those of BCA (Fig. 4), high identities of amino acid sequences between the Bra3-5 and the PlaT3-1 are reasonable. This observation also suggested that the bra genes are involved in the BCA biosynthesis though we did not detect any genes related to L-rhamnose and $\mathrm{N}$ acetylglucosamine biosyntheses in the flanking regions of the bra genes.

\section{Disruption of Cyclase Gene (bra4)}

We constructed a mutant, in which the cyclase gene (bra4) was replaced with thiostrepton resistance gene, to confirm that the gene cluster was responsible for BCA biosynthesis. A disruption plasmid, pCyc-DIS (Fig. 5A), was constructed and introduced into the BCA producer by transconjugation. Three thiostrepton-resistant colonies were randomly selected and their genomic DNAs were prepared, and used as templates for PCR analysis to study gene disruption. As shown in Fig. 5A, replacement of the bra4 gene with the thiostrepton-resistance gene by a double crossover was clearly confirmed. The disruptants and the wild type strain
(A)

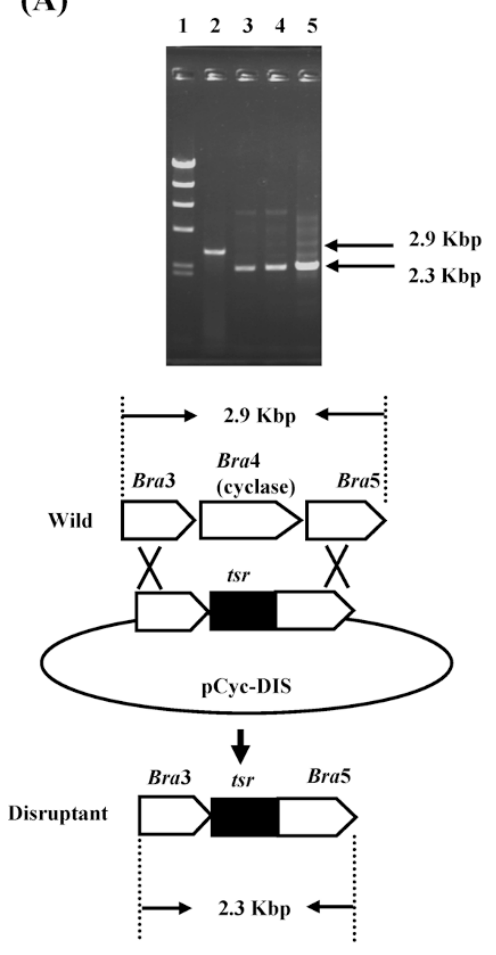

(B)

(1) Authentic BCA
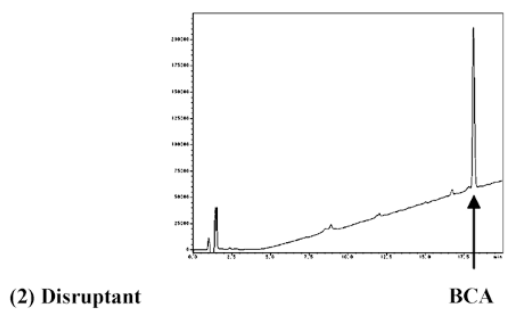

(3) Wild type
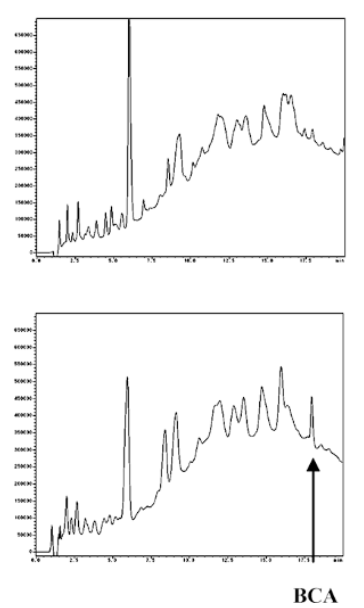

Fig. 5 PCR Analysis of the genomic DNA of the bra4 (cyclase gene)-inactivated strains (A) and BCA productivity of the disruptants (B).

(A), Molecular marker (lane 1), PCR products from genomic DNA of wild-type strain (lane 2), and of disruptant (lanes 3 5). The amplified fragments are shown schematically. Arrows indicate the primers used in PCR analysis; they correspond to the $\mathrm{N}$-terminal and $\mathrm{C}$ terminal coding region of the bra3 and bra5 genes. Filled boxes indicate the thiostrepton resistant gene (0.9 Kb). (B), Authentic BCA (1), products of disruptant (2), and products of wild-type strain (3) were analyzed by HPLC. 
were cultivated in the production medium, and their productivities of BCA were examined. None of the disruptants produced $\mathrm{BCA}$, in contrast to the wild type strain, which produced significant amounts of BCA (Fig. $5 \mathrm{~B})$. This showed that the cluster, including the putative cyclase gene (bra4), was indeed involved in the biosynthesis of BCA. We next searched for an intermediate compound in the culture broth of the bra4-disrupted strain, which would be a substrate for Bra4 (cyclase). However, we did not detect a compound specifically accumulated in the culture broth of the disruptant.

\section{Discussion}

We found recently that most actinomycete strains are equipped with only the 2- $C$-methyl-D-erythritol 4phosphate (MEP) pathway for the formation of IPP, a common precursor of isoprenoids. In addition to this pathway, we also found that a part of actinomycete strains possess both the mevalonate (MV) and MEP pathways [16]. In these strains, isoprenoid biosynthetic genes, such as terpentecin [12], BE-40644 [14, 15], viguiepinol [15] and furaquinocin A [15] were located just upstream and/or downstream of the MV pathway gene cluster. In this study, we did not exploit this observation to clone a BCA biosynthetic gene cluster because the BCA producer has only the MEP pathway and BCA was demonstrated to be synthesized via the MEP pathway [35]. Hence, we first cloned a gene encoding GGPPS, which supplies a direct precursor of diterpene compounds, and we then analyzed the flanking regions of the GGPPS gene. We expected that GGPPS genes and BCA biosynthetic genes would be clustered. We succeeded in cloning bral to brall, which might participate in BCA biosynthesis, though we did not find any genes related to L-rhamnose and $\mathrm{N}$ acetylglucosamine biosyntheses in the flanking regions of the bra genes.

An NDP-glucose-4,6-dehydratase is known to participate in the biosynthesis of L-rhamnose [36]. Hence, we tried to clone an NDP-glucose-4,6-dehydratase gene from the BCA producer by PCR and one candidate gene was successfully cloned. In the flanking region of the gene, we also identified a putative dTDP-glucose synthase gene and a dTDP-4-keto-L-rhamnose 3,5-epimerase gene, both of which are involved in the biosynthesis of L-rhamnose [36] (accession number AB268547). By gene walking analysis, however, the putative L-rhamnose biosynthetic genes and the BCA biosynthetic genes were judged to be located more than $100 \mathrm{~kb}$ apart. Considering that L-rhamnose and $\mathrm{N}$-acetylglucosamine are used for lipopolysaccharide biosynthesis and peptidoglycan biosynthesis, respectively [36], it is reasonable to assume that the L-rhamnose biosynthetic gene cluster is located at a different locus relative to the BCA biosynthetic gene cluster. In fact, Gullon et al. have cloned a biosynthetic gene cluster of steffimycin, an anthracycline compound with an Lrhamnose moiety, from Streptomyces steffisburgensis [37]. In this case, they also detected no genes related to Lrhamnose biosynthesis in the flanking regions of the steffimycin biosynthetic gene cluster.

Of the eleven bra genes, we were able to estimate the function of seven genes (bral, 2, 3, 4, 5, 10, and 11) by homology searches and by heterologous expression experiments. Although we have not postulated the detailed functions of the other genes, probable functions were estimated by intensive homology searches. The bra9 gene product showed 34\% identity to PapA5 of Mycobacterium tuberculosis, which was recently identified to be a new type of acyltransfrase that catalyzes a condensation of acyl-CoA thioesters with medium chain alcohols to give ester formation [38]. The bra7 gene product was similar to enzymes, which catalyze adenylation of specific aromatic compound, such as 3-hydroxypicolinic acid (snbA) [39], salicylate $(s \operatorname{dg} A)$ [40], and 2,3-dihydroxybenzoic acid $(m x c E)$ [41]. This activates the aromatic compounds to enable condensation with other molecules. Among them, snbA was predicted to catalyze the transfer of 3-hydroxypicolinic acid to the thiol acceptor of CoA via an adenylation step [39]. Taken together, these facts suggest that the bra7 gene product might convert 3-hydroxybenzoate into 3-hydroxybenzoyl-CoA via adenylation, followed by attachment to L-rhamnose by the bra 9 gene product. bra 6 and bra 8 had significant similarity to a P450 and to a pteridine-dependent oxidase, respectively. Considering the structure of BCA, two positions, the 2 and 16 positions, might be hydroxylated by these enzymes, although we did not investigate the exact position specificity. In conclusion, the proposed biosynthetic pathway is summarized in Fig. 4.

We have been interested in diterpene cyclases found in actinomycetes. To date, we have cloned three diterpene cyclase genes, terpentedienol diphosphate synthase (TDPS) gene $[12,13]$, tuberculosinol diphosphate synthase (TBPS) gene [42], and ent-copalyl diphosphate synthase (CDPS) gene [14]. All these genes possess a DXDD motif that mediates substrate binding, via chelation of a divalent metal ion, and catalyze cyclization reactions of GGPP by protonation at the terminal-double bond of the substrate. Moreover, we have succeeded in expression of these recombinant enzymes and characterized their properties. Hence, the bra4 gene product, which has significant 


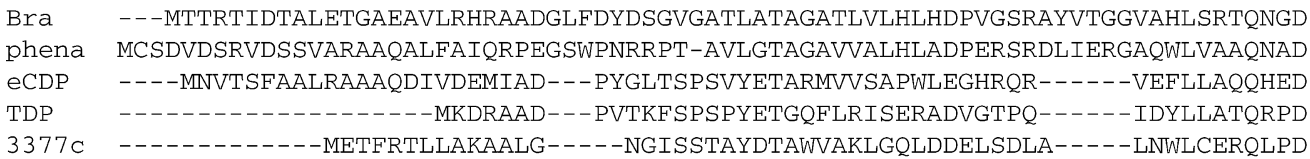

Bra GGWGSVPGQPTEAVTTAIAAAVLHLVDADGSGDRVRAGRAALDRLGGLSGIADPALSAVCHRFHAMAG-WAPPAP phena GGWGGVPRAASQLVPTVVTASALTLTAPRTAGEPARRALDLIRSLGGVESLADPGMVHMATTFLALAGLRSLHGS ECDP GTWGGP--AAYGLLPTLSAVDALLSVAGTQDAR-----------RVAGAVESGLAALAGRFPRNVELPDTIAV TDP GLWGSVG---FELVPTLGAVAGLSSRPEYADRAG----------VTDAVARACEKLWELALGEGGLPKLPDTVAS 3377C GSWGAEFPFCYEDRLLSTLAAMISLTSNKHRRRR---------AAQVEKGLLALKNLTSGAFEGPQLDIK

Bra VRVPLWVFALPR--LRRTRMSFRSGVLAATALAQARAEPGGLLRRLIDHAATPAALRVLYGIHRDEGGTGAFG-phena RRIPLELLLLPRR-LWRPRLSFRAAPFVAMAFIQAHDAAPKGVGGLLHRLARPTALRLLQEMERGENDRGGYG-ECDP ELLVPWLIEQVD--QRLSRMDDRGDLPGRLDLQADTGTLSGIRELLRQNTGIP---------EKTWHSLEALG-TDP EIIVPSLIDLLSEVLQRHRPAVGGKAGQEQEFPSPPGANAELWRQLSDRIARGQAIP-----KTAWHTLEAFHPL 3377C DATVGFELIAPTLMAEAARLGLAICHEESILGELVGVREQKLRKLGGSKINKHITAA----FSVELAGQDGVG--

Bra ADAWAAGMTGLGLVRSGAAPDLTEAIADFLRRSVFADGSWTIVE-IRLTYTGFAATGLCDAGYGADPR-----LA phena GDNWLAAVVCIGLCRTGAPAHMIAATVDYLRSNVRPDGSWHIMQGLDLIGGSYVARGLADAGYRDDPR------LA ECDP APAVRSGTVTPMGGAVGASPAATSAWLGDPPHTDAAKACLAYLHQTQARHGGPVS-GITSISYFELAW-----VV TDP PKQFAATVTPAADGAVTCSPSSTAAWLSAVG-TDAGASTRAYLDEAQSRYGGAIP-MGSSMPYFEVLW-----VL $3377 \mathrm{C}--$ MLDVDNLQETNGSVKYSPSASAYFALHVK--PGDKRALAYISSIIQAGDGGAP-AFYQAEIFEIVWSLWNLSR

Bra VTADGVRAAQLTRPFTMLDCPPGGWSYSGPDGWP---VTLESAELLSALAKMPGADRDPHVARGARWLAGRQDTR phena RARQWLRGCQQDQAFPLYDAPPGGWGWEGPHGWP---NFLDSANVLAALTPASREEPAEHLRTGLDWLVSRQDGR eCDP TALSGS-GLDVDIPAQVPDILRTALGANGLSAGPG--LPADSDDTSAALHALDLLGKPESVDCLWEYDTG----TDP NLVLKY-FPDVPIPREIIEEIAAGFSDSGIGGGPG--LPPDGDDTAYANLAGDKLGAPTHPEILMKFWAED---3377C TDIDLSDPEIVRTYLPYLDHVEQHWVRGRGVGWTGNSTLEDCDTTSVAYDVLSKFGRSPDIGAVLQFEDAD----

Bra GSWSLWVRDTALANDGPCPYLTAQAVDALLDAGIPPEDNGIRRAARWLAGVQRPD-GSFESLWYRGHTAGTAQVI phena GSWGTFVPDTTLANDGPCPYTTAQCVESLLDGGLSRGDPRIAKALDWLLAAQRPD-GTYEALWYRGLTAATATAL ECDP LYFTCF PKERTPSTSTNAHILVALADR--RGQGDTRYDHAAERVGGWLVEQQQPD-GRWMDKWHASPYYATACGA TDP -HFVSYPGEQTPSETVNAHALEYLNHLR-MRRGITEFGAVEDACAEWVISQQTED-GCWYDKWNVSPYYSTAACV $3377 \mathrm{C}$-WFRTYFHEVGPSISTNVHVLGALKQA----GYDKCHPRVRKVLEFIRSSKEPGRFCWRDKWHRSAYYTTAHLI

Bra GALARIT--DPATDPTVRGGVRWLLATQHSDGSWGPGDG-------RAGSVEETAWALRALLEAGIAPG-TAEID phena VALARG---GVGDHPAARRAREALLAGQLADGSWGPGDTGTPGDDPSRGTVEETAWALRGLLAAGLPAQ-DDRLR ECDP AAMARLD--GPRTSAALDDAIRWVLDTQHADGSWGRWEG--------TGEETAYALQVLNHRAAPDRPALEAI TDP EALLDARKQDEPQLDSLRRAREWLLRHQTDSGGWGMAEP--------SPEETAYAVLALDLFASRGGEGAEEC 3377 C CAASNYD----DALCSDAIGWILNTQRPDGSWGFFDG-------QATAEETAYCIQALAHWQRHSG----TS

Bra RAADWLLARQQPDGHWPEAPVSAYIRRCVHYPNGAITAGLALRALAAYRRGLGR----KDDDG phena RAAEWIVSAQGDDGLWDANPVCLHIRRLAYYADGLIGNGLVLRALGAYRSALAAGPVARREAS ECDP RAGRAFLSGHVEDDRRNPP---LWHDKDLYTPVRVIRAEILGTLAATQRLAEAE----KEARA TDP AAAISRAKEFFTDESRENPP--LWMGKDLYTPFRIVDVTVMCGRAVVGRY---------3377C LSAQISRAGGWLSQHCEPPYAPLWIAKTLYCSATVVKAAILSALRLVDESNQ-------.--

Fig. 6 Alignment of eubacterial diterpene cyclases.

Multiple alignment of the bra4 gene product (Bra) with PlaT2 (phena), ent-copalyl diphosphate synthase (eCDP), terpentedienol diphosphate synthase (TDP), and tuberculosinol diphosphate synthase (Rv3377c) is shown. Aspartate rich regions that are known to be responsible for substrate binding are underlined.

similarity to diterpene cyclases, was also expressed as a recombinant enzyme and used in an in vitro assay, using GGPP as a substrate. However, we detected no reaction products under various conditions. Very recently, a biosynthetic gene cluster of phenalinolactone, a diterpene compound, was cloned from Streptomyces sp. Tü6071 by searching for an NDP-glucose-4,6-dehydratase gene that participates in the formation of L-amicetose attached to an aglycon of phenalinolactone [34]. In the cluster, the plaT2 gene has significant similarity to isoprenoid cyclases and is annotated to be a diterpene cyclase responsible for the biosynthesis of phenalinolactone. They suggested that the
plaT2 product uses epoxy-GGPP as a substrate based on the following observations: The plaT1 gene, which is located just downstream of the plaT2 gene, had significant similarity to eukaryotic squalene epoxidase genes and the plaT2 product lacked a DXDD motif, in a similar manner to those of oxidosqualene cyclases that use epoxy-squalene as a substrate. To predict whether the bra 4 gene product would also function in a similar manner, a multiple alignment of TDPS, TBPS, CDPS, PlaT2 and Bra4 was constructed using the ClustalW program [43]. As shown in Fig. 6, both PlaT2 and Bra4 had no typical DXDD motif, in contrast to TDPS, TBPS, and CDPS. Moreover, the 
bra5 product had significant identity to PlaT1. Taking these results together, Bra4 might use epoxy-GGPP as a substrate. To examine this possibility, an in vitro experiment is essential. This study is now in progress and will be reported in the near future.

Acknowledgments We thank Mrs. S. Miyakage and K. Ogawa for their excellent technical assistance. This work was supported, in part, by a Grant-in-Aid for Scientific Research (C) to D. T (number 18018035).

\section{References}

1. Connolly JD, Hill RA. Dictionary of terpenoids, Chapman and Hall, NY (1992)

2. Dewick PM. The biosynthesis of $\mathrm{C} 5 \sim \mathrm{C} 25$ terpenoid compounds. Nat Prod Rep 19: 181-222 (2002)

3. Wise ML, Croteau R. Comprehensive natural products chemistry no. 2, isoprenoids, including carotenoids and steroids. pp. 97-153, Elsevier Science, Oxford (1999)

4. Cane DE. Comprehensive natural products chemistry no. 2, isoprenoids, including carotenoids and steroids. pp. 155-200, Elsevier Science, Oxford (1999)

5. MacMillan J, Beale MH. Comprehensive natural products chemistry no. 2, isoprenoids, including carotenoids and steroids. pp. 217-243, Elsevier Science, Oxford (1999)

6. Bohlmann J, Meyer-Gauen G, Croteau R. Plant terpenoid synthases: Molecular biology and phylogenetic analysis. Proc Natl Acad Sci USA 95: 4126-4133 (1998)

7. Trapps S, Croteau R. Defensive resin biosynthesis in conifers. Annu Rev Plant Physiol Plant Mol Biol 52: 689-724 (2001)

8. Keeling CI, Bohlmann J. Genes, enzymes and chemicals of terpenoid diversity in the constitutive and induced defense of conifers against insects and pathogens. New Phytol 170: 657-675 (2006)

9. Cane DE, Sohng JK, Lamberson CR, Rudnicki SM, Wu Z, Lloyd MD, Oliver JS, Hubbard BR. Pentalenene synthase: purification, molecular cloning, sequencing, and high-level expression in Escherichia coli of a terpenoid cyclase from Streptomyces UC5319. Biochemistry 33: 5846-5857 (1994)

10. Lin X, Hopson R, Cane DE. Genome mining in Streptomyces coelicolor: molecular cloning and characterization of a new sesquiterpene synthase. J Am
Chem Soc 128: 6022-6023 (2006)

11. Jiang J, He X, Cane DE. Geosmin biosynthesis. Streptomyces coelicolor germacradienol/germacrene D synthase converts farnesyl diphosphate to geosmin. J Am Chem Soc 128: 8128-8129 (2006)

12. Dairi T, Hamano Y, Kuzuyama T, Itoh N, Furihata K, Seto H. Eubacterial diterpene cyclase genes essential for production of the isoprenoid antibiotic terpentecin. J Bacteriol 183: 6085-6094 (2001)

13. Hamano Y, Kuzuyama T, Itoh N, Furihata K, Seto H, Dairi T. Functional analysis of eubacterial diterpene cyclases responsible for biosynthesis of a diterpene antibiotic, terpentecin. J Biol Chem 277: 37098-37104 (2002)

14. Kawasaki T, Kuzuyama T, Kuwamori Y, Matsuura N, Itoh N, Furihata K, Seto H, Dairi T. Presence of copalyl diphosphate synthase gene in an actinomycete possessing the mevalonate pathway. J Antibiot 57: 739-747 (2004)

15. Kawasaki T, Hayashi Y, Kuzuyama T, Furihata K, Itoh N, Seto H, Dairi T. Biosynthesis of a natural polyketideisoprenoid hybrid compound, furaquinocin A: identification and heterologous expression of the gene cluster. J Bacteriol 188: 1236-1244 (2006)

16. Dairi T. Studies on biosynthetic genes and enzymes of isoprenoids produced by actinomycetes. J Antibiot 58: 227-243 (2005)

17. Komaki H, Nemoto A, Tanaka Y, Takagi H, Yazawa K, Mikami Y, Shigemori H, Kobayashi J, Ando A, Nagata Y. Brasilicardin A, a new terpenoid antibiotic from pathogenic Nocardia brasiliensis: fermentation, isolation and biological activity. J Antibiot 52: 13-19 (1999)

18. Komaki H, Tanaka Y, Yazawa K, Takagi H, Ando A, Nagata Y, Mikami Y. Antitumor activity of brasilicardin A, a novel terpenoid antibiotic from Nocardia brasiliensis. J Antibiot 53: 75-77 (2000)

19. Shigemori H, Komaki H, Yazawa K, Mikami Y, Nemoto A, Tanaka Y, Sasaki T, In Y, Ishida T, Kobayashi J. Brasilicardin A. A novel tricyclic metabolite with potent immunosuppressive activity from actinomycete Nocardia brasiliensis. J Org Chem 163: 6900-6904 (1998)

20. Komatsu K, Tsuda M, Tanaka Y, Mikami Y, Kobayashi, J. SAR studies of brasilicardin A for immunosuppressive and cytotoxic activities. Bioorg Med Chem 13: 1507-1513 (2005)

21. Maniatis T, Fritsch EF, Sambrook J. Molecular cloning. A 
laboratory manual, Cold Spring Harbor Laboratory, NY (1982)

22. Hamano Y, Dairi T, Yamamoto M, Kawasaki T, Kaneda K, Kuzuyama T, Itoh N, Seto H. Cloning of a gene cluster encoding enzymes responsible for the mevalonate pathway from a terpenoid-antibiotic-producing Streptomyces strain. Biosci Biotechol Biochem 65: 1627-1635 (2001)

23. Kawasaki T, Kuzuyama T, Furihata K, Itoh N, Seto H, Dairi T. A relationship between the mevalonate pathway and isoprenoid production in actinomycetes. J Antibiot 56: 957-966 (2003)

24. Dairi T, Ohta T, Hashimoto E, Hasegawa M. Organization and nature of fortimicin A (astromicin) biosynthetic genes studied using a cosmid library of Micromonospora olivasterospora DNA. Mol Gen Genet 236: 39-48 (1992)

25. Kawasaki T, Hamano Y, Kuzuyama T, Itoh N, Seto H, Dairi T. Interconversion of the product specificity of type I eubacterial farnesyl diphosphate synthase and geranylgeranyl diphosphate synthase through one amino acid substitution. J Biochem 133: 83-91 (2003)

26. Hopwood DA, Bibb MJ, Chater KF, Kieser T, Bruton CJ, Kieser HM, Lydiate DJ, Smith CP, Ward JM, Schremp H. Gene Manipulation of Streptomyces. A laboratory manual, The John Innes Foundation, Norwich, UK (1985)

27. Schafer A, Tauch A, Jager W, Kalinowski J, Thierbach G, Puhler A. Small mobilizable multi-purpose cloning vectors derived from the Escherichia coli plasmids pK18 and pK19: selection of defined deletions in the chromosome of Corynebacterium glutamicum. Gene 145: 69-73 (1994)

28. Onaka H, Taniguchi S, Igarashi $\mathrm{Y}$, Furumai $\mathrm{T}$. Characterization of the biosynthetic gene cluster of rebeccamycin from Lechevalieria aerocolonigenes ATCC 39243. Biosci Biotechol Biochem 67: 127-138 (2003)

29. Bentley SD, Chater KF, Cerdeno-Tarraga AM, Challis GL, Thomson NR, James KD, Harris DE, Quail MA, Kieser H, Harper D, Bateman A, Brown S, Chandra G, Chen CW, Collins M, Cronin A, Fraser A, Goble A, Hidalgo J, Hornsby T, Howarth S, Huang CH, Kieser T, Larke L, Murphy L, Oliver K, O'Neil S, Rabbinowitsch E, Rajandream MA, Rutherford K, Rutter S, Seeger K, Saunders D, Sharp S, Squares R, Squares S, Taylor K, Warren T, Wietzorrek A, Woodward J, Barrell BG, Parkhill J, Hopwood DA. Complete genome sequence of the model actinomycete Streptomyces coelicolor A3(2). Nature 417: 141-147 (2002)

30. Omura S, Ikeda H, Ishikawa J, Hanamoto A, Takahashi C, Shinose M, Takahashi Y, Horikawa H, Nakazawa H, Osonoe
T, Kikuchi H, Shiba T, Sakaki Y, Hattori M. Genome sequence of an industrial microorganism Streptomyces avermitilis: Deducing the ability of producing secondary metabolites. Proc Natl Acad Sci USA 98: 12215-12220 (2001)

31. Hayashi Y, Onaka H, Itoh N, Seto H, Dairi T. Cloning of the gene cluster responsible for biosynthesis of KS-505a (longestin), a unique tetraterpenoid. Biosci Biotechol Biochem 71: 3072-3081 (2007)

32. Altschul SF, Gish W, Miller W, Myers EW, Lipman DJ. Basic local alignment search tool. J Mol Biol 215: 403-410 (1990)

33. Pearson WR, Lipman DJ. Improved tools for biological sequence comparison. Proc Natl Acad Sci USA 85: 2444-2448 (1988)

34. Durr C, Schnell HJ, Luzhetskyy A, Murillo R, Weber M, Welzel K, Vente A, Bechthold A. Biosynthesis of the terpene phenalinolactone in Streptomyces sp. Tü6071: Analysis of the gene cluster and generation of derivatives. Chem Biol 13: 365-377 (2006)

35. Shigemori H, Komaki H, Yazawa K, Mikami Y, Nemoto A, Tanaka Y, Kobayashi J. Biosynthesis of diterpene moiety of brasilicardin A via non-mevalonate pathway in Nocardia brasiliensis. Tetraherdon Lett 40: 4353-4354 (1999)

36. Trefzer A, Salas JA, Bechthold A, Genes and enzymes involved in deoxysugar biosynthesis in bacteria. Nat Prod Rep 16: 283-399 (1999)

37. Gullon S, Olano C, Abdelfattah MS, Brana AF, Rohr J, Mendez C, Salas JA. Isolation, characterization, and heterologous expression of the biosynthesis gene cluster for the antitumor anthracycline steffimycin. Appl Environ Microbiol 72: 4172-4183 (2006)

38. Onwueme KC, Ferreras JA, Buglino J, Lima CD, Quadri LEN. Mycobacterial polyketide-associated proteins are acyltransferases: Proof of principle with Mycobacterium tuberculosis PapA5. Proc. Natl. Acad. Sci. USA 101: 4608-4613 (2004)

39. Crecy-Lagard V, Blanc V, Gil P, Naudin L, Lorenzon S, Famechon A, Bamas-Jacques M, Crouzet J, Thibaut D. Pristinamycin I biosynthesis in Streptomyces pristinaespiralis: molecular characterization of the first two structural peptide synthetase genes. J Bacteriol 179: 705-713 (1997)

40. Ishiyama D, Vujaklija D, Davies J. Novel pathway of salicylate degradation by Streptomyces sp. Strain WA46. 
Appl Environ Microbiol 70: 1297-1306 (2004)

41. Silakowski B, Kunze B, Nordsiek G., Blöcker H, Höfle G, Muller R. The myxochelin iron transport regulon of the myxobacterium Stigmatella aurantiaca $\mathrm{Sg}$ a15. Eur J Biochem 267: 6476-6485 (2000)

42. Nakano C, Okamura T, Sato T, Dairi T, Hoshino $T$.
Mycobacterium tuberculosis H37Rv 3377c encodes the diterpene cyclase for producing halimane skeleton. Chem Commun Issue 8: 1016-1018 (2005)

43. Thompson JD, Higgins DG, Gibson TJ. CLUSTALW. Nucleic Acids Res 22: 4673-4680 (1994) 